\title{
EKSISTENSI PEMBERLAKUAN SISTEM E-COURT DALAM PERADILAN TATA USAHA NEGARA DI INDONESIA
}

\author{
Krisyulaeni \\ Universitas Negeri Semarang \\ Email: krisyulaeni56@gmail.com
}

\begin{abstract}
The massive rate of technological development that is happening in Indonesia today, has led various judicial bodies in all parts of the world, including Indonesia to then begin to adopt and take advantage of these technological developments. The procurement of e-court itself began to be implemented after the Supreme Court Regulation Number 3 of 2018. PTUN which stands for the term State Administrative Court is one of the judicial institutions in Indonesia whose position is under the Supreme Court. The Supreme Court itself has made various efforts through convenience in terms of administrative services through a system called the electronic court or hereinafter referred to as e-court, and then by law, this is contained in Supreme Court Regulation Number 1 of 2019.
\end{abstract}

\section{Keywords: Technological developments, Electronic courts, State Administrative Courts}

\section{PENDAHULUAN}

Terdapat sebuah adagium hukum yaitu "ubi societas, ibi ius", sebagaimana maknanya yaitu di mana terdapat suatu masyarakat maka disitu juga pasti ada hukum. Berdasarkan kalimat tersebut, maka dapat diketahui bahwa pada hakikatnya hukum selalu berjalan beriringan dengan perkembangan masyarakat. Seorang tokoh hukum, yaitu Paul Scholten mengatakan bahwasanya sejatinya sistem hukum termasuk kedalam sistem yang terbuka ${ }^{1}$. Hukum ialah masyarakat itu juga, maka itu artinya hubungan masyarakat baru akan membentuk sebuah aturan baru pula². Sehingga, terkait dengan pendapat yang mana menjelaskan bahwa hukum merupakan suatu ilmu yang selalu tertinggal daripada laju perkembangan masyarakat harus kita maknai hanya sebatas pada hukum tertulis saja yang mana pada hakikatnya menjadi sebuah dokumen semata.

\footnotetext{
1 Paul Scholten. Penuntun Dalam Mempelajari Hukum Perdata Belanda. Yogyakarta, Gadjah Mada University Press, 1993, hlm. 103.

2 Van Apeldoorn. Pengantar Ilmu Hukum. Jakarta, Pradnya Paramita, 1986, hlm. 18.
} 
Perlu kita ketahui bahwa hukum sebagai prinsip serta nilai moral akan selalu berkembang dan bergerak secara dinamis mengikuti segala perkembangan yang terjadi pada masyarakat. Alfin Toffler mengatakan bahwa pada era dunia Gelombang Ketiga, perkembangan peradaban masyarakat sudah memasuki peristilahan yang dicetuskan oleh seorang tokoh bernama Rhenald Kasali, yaitu Model Peradaban Uber $^{3}$. Pada tahap tersebut memiliki ciri-ciri yaitu adanya revolusi peradaban yang semula sebagai time series, saat ini berubah dengan istilah lain yaitu real time, sikap individualis berubah menjadi saling membuat suatu perkumpulan atau berkolaborasi, multitasking, dan adanya kompetitor yang tidak terlihat ${ }^{4}$.

Dengan adanya laju perkembangan teknologi dalam hal ini yaitu dalam Peradaban Uber ini sebagaimana yang telah dijelaskan sebelumnya, tentu hal tersebut mempengaruhi sistem Peradilan Tata Usaha Negara kita, Indonesia. Apabila sebelumnya aktivitas pengadministrasian suatu perkara dilakukan secara manual yang mana keadaan itu akan membawa kepada ketidak efisiensian waktu serta tentu memakan biaya yang juga cukup tinggi, dalam hal ini teknologi informasi telah memberikan pengaruhnya yaitu dalam hal mempercepet serta memudahkan sekaligus efisiensi biaya dalam proses pengadministrasian suatu perkara pada Peradilan Tata Usaha Negara 5 .

Definisi dari PTUN sendiri yaitu sebagai pelaksana kekuasaan kehakiman yang mana ia memiliki tugas serta wewenang diantaranya yaitu guna melakukan pemeriksaan, pemutusan, serta melakukan penyelesaian sengketa Tata Usaha Negara (TUN) ${ }^{6}$. Suatu kekuasaan kehakiman memiliki definisi sebagai sebuah kekuasaan merdeka yang mana berfungsi sebagai penyelenggaraan peradilan yang dimaksudkan untuk mengadakan proses penegakkan hukum serta menjamin untuk mencapai sebuah keadilan yang mana kekuasaan kehakiman ini diselenggarakan oleh Mahkamah Agung berikut dengan lembaga peradilan dibawahnya meliputi lingkup peradilan agama, peradilan umum, peradilan TUN, peradilan militer, serta Mahakamah Konstitusi.

Lain halnya apabila ketiga lingkup peradilan yang telah disebutkan sebelumnya yang mana berada dibawah kekuasaan Mahkamah Agung, Peradilan Tata Usaha Negara

\footnotetext{
3 Rhenald Kasali. Disruption, Penerbit PT Gramedia Pustaka Utama, Jakarta, 2017, hlm. 21.

4 Ibid, hlm. 21-23.

5 Sudarsono. Penerapan Peradilan Elektronik Di Lingkungan Peradilan Tata Usaha Negara. Jurnal Hukum Peratun, Volume 1 Nomor 1, Jakarta: 2011, hlm. 59.

6 Agus, Elfran. Persidangan Elektronik E-Litigasi Pada Peradilan Tata Usaha Negara. Paulus Law Journal, Volume 2 Nomor 1, 2020, hlm. 15.
} 
(PTUN) ini datang untuk melakukan penyelenggaraan dan pengimplementasian kekuasaan kehakiman supaya dapat mengatasi berbagai perkara yang dianggap sebagai suatu sengketa tata usaha negara termasuk kedalamnya yaitu permohonan terkait dengan persoalan wewenang dalam melaksanakan peradilan dalam pengadilan tata usaha negara ${ }^{7}$.

\section{IDENTIFIKASI MASALAH}

Penulis akan memberikan batasan permasalahan yang akan dibahas dalam penelitian ini, yaitu:

1. Apakah Sistem Peradilan E-court dalam Peradilan Tata Usaha Negara telah diatur dalam perundang-undangan?

2. Apakah implikasi dari system E-court dapat memberikan kemajuan dalam perkembangan peradilan di Indonesia?

\section{METODE}

Pada penelitian tersebut, penulis menggunakan metode penelitian yuridis normatif yaitu suatu proses untuk menemukan serta mencapai aturan hukum, sebagai bahan dalam merespon isu hukum yang dihadapi serta hukum dikonsepkan sebagai norma ataupun kaidah yang dijadikan landasan manusia dalam berperilaku. Sedangkan pendekatan yang dimanfaatkan dalam penelitian ini sebagai jawaban dari sebuah spekulasi hukum yaitu pendekatan peraturan perundang-undangan serta pendekatan konseptual. Kemudian, Pendekatan konseptual, dalam hal ini yaitu dilaksanakan melalui beberapa cara diantaranya yaitu mengidentifikasi,mengkaji serta kemudian menganalisis konsep hukumnya yang mana dimungkinkan memiliki relevansi dengan pokok bahasan yang termuat pada penelitian ini, yaitu konsep penyelesaian perkara, konsep hukum acara, konsep administrasi perkara serta yang paling utama dalam pembahasan ini adalah konsep peradilan secara elektronik.

\section{HASIL DAN PEMBAHASAN}

Prajudi Atmosudirdjo, mengatakan bahwasanya tujuan dari pembentukan peradilan administrasi negara atau yang kemudian di sebut dan disingkat dengan (PTUN) ialah untuk memberikan fasilitas hukum berupa perlindungan terhadap masyarakat Indonesia sebagaimana yang sering kita lihat dan ketahui yaitu terkait dengan kepentingan hukumnya

\footnotetext{
${ }^{7}$ Ibid, hlm. 15-16.
} 


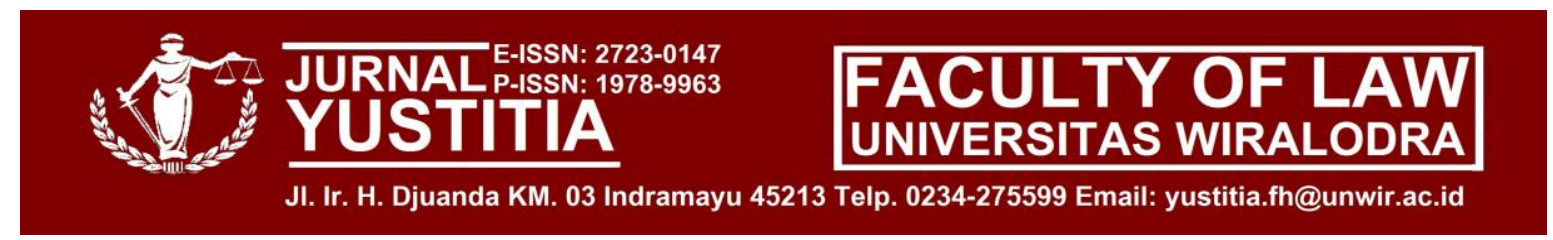

yang seringkali terasingkan atau terdesak oleh karena semakin meluasnya kepentingan penguasa yang seringkali berbenturan dan mengancam eksistensi masyarakat yang sudah sejak lama mempertahankan keyakinan maupun suatu ketentuan tertentu dalam lingkungan dan atau wilayahnya.

Oleh karena itu, melalui Peradilan Tata Usaha Negara, masyarakat bisa melakukan pengajuan serta melayangkan suatu gugatan tertentu terhadap penguasa apabila suatu saat terjadi suatu sehingga untuk kemudian memperoleh tindakan korektif dari Peradilan Tata Usaha Negara tersebut. Kemudian, seorang tokoh bernama Sjachran Basah, mengemukakan pendapatnya terkait dengan tujuan diadakannya PTUN, bahwa menurutnya tujuan dari PTUN ini yaitu sebagai upaya guna memberikan jaminan dalam hal pengayoman hukum, tidak serta merta hanya kepada masyarakat semata, akan tetapi juga untuk lembaga administrasi negara dalam artian yaitu guna menjaga serta memelihara keseimbangan antara kepentingan masyarakat dengan kepentingan individu ${ }^{8}$. Kemudian, seiring dengan berlalunya masa dan perkembangan yang dialami serta dilalui oleh manusia berkaitan dengan teknologi saat ini, terdapat sistem yang dapat dibilang masih cukup baru dengan pengaturannya yang terbilang baru pula yaitu pada Peraturan Mahkamah Agung Nomor 1 Tahun 2019, yang mengatur tentang peradilan elektronik atau yang biasa kita sebut dengan E-Court. Untuk itu, maka kita terlebih dahulu harus mengetahui terkait dengan konsep peradilan Tata Usaha Negara melalui sistem E-court ini.

Dalam pemeriksaan perkara Tingkat Pertama pada PTUN ini sendiri dimulai dari perkara Gugatan serta perkara permohonan. Apabila mengacu pada teori, maka suatu perkara Gugatan diartikan menjadi suatu perkara yang mana memuat suatu sengketa ataupun suatu konflik yang penting untuk segara dirampungkan untuk kemudian diputus oleh pihak pengadilan, kemudian bagi perkara Permohonan sendiri diajukan bukan karena adanya suatu sengketa, yang mana dalam hal ini hakim mengeluarkan sebuah ketetapan yang mana bersifat menetapkan ataupun hanya sekadar menerangkan.Selanjutnya secara normatif, definisi dari Perkara Gugatan ialah sebuah pemeriksaan atas sebuah tuntutan seseorang terhadap Peradilan Tatat Usaha Negara agar Keputusan serta Tindakan Badan ataupun Pejabat Pemerintahan tersebut dinyatakan batal atau dalam hal ini yaitu tidak sah,

\footnotetext{
8 Putera Astomo, Eksistensi Peradilan Administrasi Dalam Sistem Negara Hukum Indonesia. MMH, Jilid 43
} No. 3, Semarang, hlm. 369. 


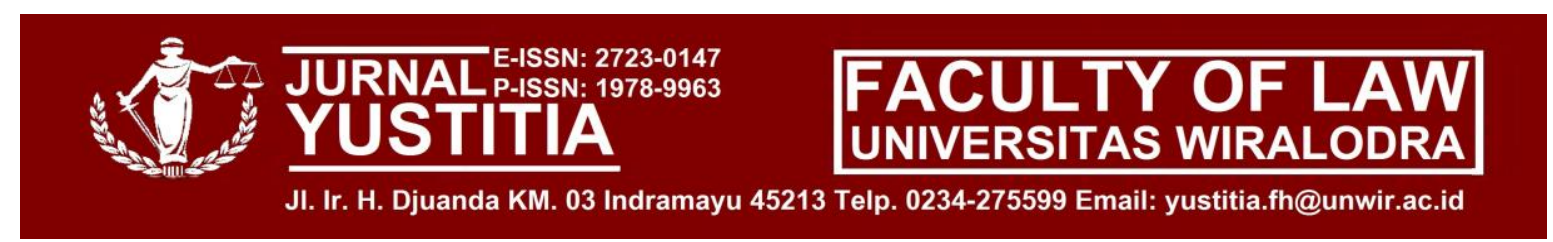

seperti yang dimuat dalam Pasal 1 angka 11 jo Pasal 53 ayat (1) UU Peradilan TUN serta Pasal 87 UUAP.

Sebelum lanjut pada pembahasan berikutrnya, maka akan lebih afdhal rasanya apabila kita mengetahui terlebih dahulu terkait dengan asal mula atau sejarah dari dibentuknya Peradilan Tata usaha Negara, Peradilan Tata Usaha Negara atau yang biasa kita kenal dengan istilah PTUN, ini terbentuk pada saat rezim Orde Baru,hal tersebut terjadi dalam selang 5 tahun setelah diberlakukannya Undang-Undang Nomor 5 Tahun 1986 tentang Peradilan Tata Usaha Negara berdasarkan Keputusan Presiden Nomor 52 Tahun 1990 tentang Pembentukan Pengadilan Tata Usaha Negara Yang mana Bertempat di beberapa kota besar diantaranya yaitu Jakarta, Medan, Palembang, Surabaya, serta Ujung Pandang, dan pembentukan PTUN di Jakarta, Medan, serta Ujung pandang Berdasar kepada Keputusan Presiden Nomor 10 tahun 19909.

Eksistensi dari Peradilan Tata Usaha Negara sebelum dimulainya era orde baru sebenarnya sudah terlihat baik itu di dalam aturan aturan hukum yang berlaku maupun dalam konstitusi, termasuk didalamnya yaitu terkait dengan adanya wacana tentang pembentukan Peradilan Tata Usaha Negara yang mana hal tersebut tercantum pada sebuah TAP MPRS RI Nomor II/MPRS/1960 dengan isinya yaitu suatu perintah untuk segera diadakan suatu Peradilan Administrasi Negara ${ }^{10}$ Oleh karena itu, tepatnya pada tahun 1960, Lembaga Pembinaan Hukum Nasional melakukan sebuah penyusunan pada naskah Rancangan Undang-Undang tentang Peradilan Administrasi Negara ${ }^{11}$. PTUN sendiri merupakan bagian dari pelaksana kekuasaan kehakiman yang juga didalamnya diperuntukkan untuk masyarakat dalam mencari sebuah keadilan yang dihadapinya semissal dalam kasus sengketa Tata Usaha Negara.

PTUN, selaku sebuah lembaga yang turut menyelenggarakan kekuasaan kehakiman tentu saja memiliki tugas atau kewajiban serta wewenang dan atau hak untuk melakukan beberapa hal, diantaranya sebagai berikut memeriksa, memutus, serta menyelesaikan sebuah sengketa Tata Usaha Negara (TUN) tentunya. Kemudian, sengketa TUN sendiri ialah merupakan sengketa, yang mana didalam sengketa tersebut timbul didalam suatu ranah tata usaha negara yang terdiri beberapa orang maupun suatu badan atau pejabat tata

\footnotetext{
9 Zairin Harahap, Hukum Acara Peradilan Tata Usaha Negara, Rajawali Pers, Jakarta, 2015, hlm. 28.

${ }^{10}$ Philipus M. Hadjon, Pengantar Hukum Administrasi Indonesia Introduction to the Indonesian Administrative Law, Gajah Mada University Press, Yogyakarta, hlm. 4-3.

${ }^{11}$ S.F. Marbun, 2003, Peradilan Tata Usaha Negara, Liberty, Yogyakarta, hlm. 8-9.
} 


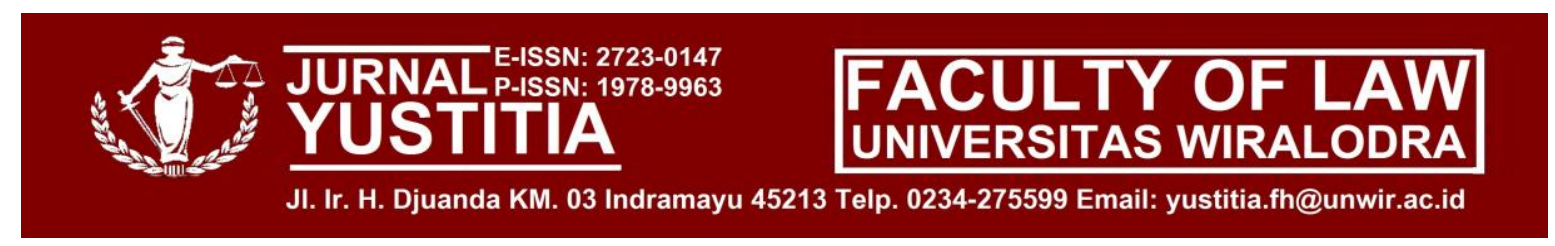

usaha negara dengan badan hukum perdata, baik itu pada tingkat pusat ataupun daerah, sebagai suatu sanksi dari dikeluarkannya keputusan tata usaha negara, termasuk didalamnya yaitu sengketa kepegawaian yang dilandaskan pada peraturan perundangundangan. Berdasarkan kepada ketentuan Undang-Undang PTUN, maka sudah pasti memposisikan pihak-pihak yang bersengketa yaitu antara orang maupun badan hukum perdata dengan pejabat Tata Usaha Negara.

Sebenarnya, di dalam sebuah sengketa kepegawaian pada lingkungan administrasi negara yang mana akan menjadi kewenangan dalam hal mengadili atau dalam pengadilan yaitu oleh PTUN, dengan catatan yaitu sesudah menempuh sebuah usaha penyelesaian secara administratif, dimana usaha tersebut ditetapkan sebelumnya menurut UndangUndang ${ }^{12}$. Berkaitan dengan pengadaan E-Court di Indonesia, dan pada khususnya yaitu dalam penerapan pada Peradilan Tata Usaha Negara, hal tersebut telah diatur dalam Peraturan Mahkamah Agung No. 1 Tahun 2019 tentang Administrasi Perkara Pengadilan secara Elektronik, yang mana dalam peraturan tersebut terkandung arti bahwa peraturan Mahkamah Agung Nomor 1 Tahun 2019 tersebut yang memberi amanat terhadap pemerintah untuk menyokong salah satu bentuk kemajuan teknologi tersebut lewat upaya peningkatan infrastruktur hukum beserta pengaturannya sehingga pengadaan pemanfaatan teknologi tersebut dapat diadakan serta dilaksanakan dengan aman guna mencegah adanya kemungkinan penyalahgunaan dengan tetap mempertimbangkan serta memperhatikan beberapa nilai yang menjadi pedoman mnegara Indonesia diantaranya yaitu nilai agama serta nilai sosial budaya.

Menyikapi persoalan tersebut, khususnya di dunia hukum dalam hal ini dituntut untuk melakukan suatu perubahan yang progresif dalam melaksanakan tindakan hukum, diantaranya yaitu dalam bentuk e-court dalam Peradilan Tata Usaha Negara sesuai dengan topik pembahasan kali ini. Tepatnya pada tanggal 10 Oktober 2019, layanan e-court telah terdapat di seluruh peradilan umum di Indonesia dan tentunya termasuk didalamnya yaitu Peradilan Tata Usaha Negara. Dalam persidangan PTUN melalui sistem e-court, maka terkait dengan teknis dalam persidangan diselenggarakan secara elektronik dimana hal tersebut memiliki tujuan untuk mempersempit kemungkinan adanya persidangan secara langsung yang melibatkan pihak yang bersangkutan serta memperkecil adanya

\footnotetext{
${ }^{12}$ Gracia, Majolica, Ronaldo, Eksistensi E-Court Untuk Mewujudkan Efisiensi dan Efektivitas Pada sistem Peradilan Indonesia Di Tengah Covid 19. Jurnal Syntax Transformation, 2021, Vol. 2 No. 4.
} 


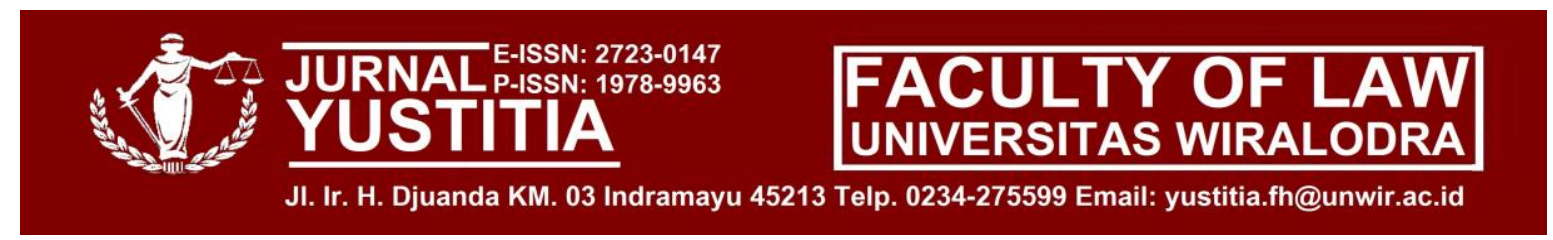

kemungkinan besar kehadiran pihak dimuka pengadilan sebagai upaya dalam mewujudkan asas-asas tertentu yang dianggap baik dan semakin meningkatkan keesisiensian serta keefektifan persidangan, diantaranya yaitu asas sederhana, cepat, dan biaya ringan, oleh karena itu maka hal ini tentu akan meringankan semua pihak dengan berbagai jenis keringanannya ${ }^{13}$.

Berdasarkan kepada Peraturan Mahkamah Agung No. 1 Tahun 2019 tentang Administrasi Perkara dan Persidangan di Pengadilan secara Elektronik ${ }^{14}$, oleh karenanya proses pelayanan administrasi perkara serta persidangan ini dilaksanakan secara elektronik sebagai bagian dari upaya untuk mewujudkan adanya reformasi dalam dunia peradilan guna mendongkrak perkembangan teknologi informasi pada suatu hukum acara yang mana hal tersebut sejatinya telah selaras dengan adanya perkembangan serta kemajuan zaman yang hingga kini telah mencapai suatu era yang modern. E-court sendiri merupakan suatu perangkat atau dapat pula kita katakan sebagai suatu sistem dalam proses peradilan yang mana ia merupakan bentuk dari pelayanan mulai dari proses pendaftaran perkara melalui sistem elektronik.

Dalam sebuah proses pengembangan beserta penerapan e-court ini tentunya harus diselenggarakan secara lebih terencana serta sistematis. E-litigasi ini merupakan suatu sistem dengan serangkaian proses pemeriksaan beserta proses mengadili dalam suatu perkara oleh pengadilan,untuk konteks ini yaitu Pengadilan Tata Usaha Negara melalui sokongan akibat dari kemajuan sistem teknologi informasi dan komunikasi di Indonesia Sebelum lahirnya peraturan baru mengenai pelaksanaan E-court, yaitu pada Maret 2018, terdapat sebuah Peraturan Mahkamah Agung No. 3 Tahun 2018 yang mana dalam peraturan ini memuat tentang muatan dalam membangun aplikasi e-court.

Kemudian selanjutnya, terjadi sebuah peluncuran serta sistem perngujian dari ecourt. Kemudian tahun 2019 para pengadaan e-court di seluruh wilayah pengadilan di Indonesia, terutama dalam konteks materi ini yaitu peradilan tata usaha negara. Lalu pada bulan Agustus tahun 2019, terjadi sebuah luncuran e-litigasi di wilayah peradilan tata usaha negara Indonesia. Dan pada bulan September 2019, dilaksanakanlah sebuah uji coba

\footnotetext{
${ }^{13}$ Indonesia, K.K.R.I. Efektivitas Dan Efisiensi Penggunaan E-Court Di Kpknl Jambi Pada EraTatanan Normal Baru. 2020. Https://Www.Djkn.Kemenkeu.Go.Id/KpknlJambi/BacaArtikel/13461/EfektivitasDanEfisiensi-Penggunaan-E-Court-DiKpknlJambi-Pada-Era-TatananNormal-Baru.html, Diakses Pada 28 Agustus 2021.

${ }^{14}$ Peraturan Mahkamah Agung No. 1 Tahun 2019 Tentang Administrasi Perkara dan Persidangan Di Pengadilan Secara Elektronik.
} 


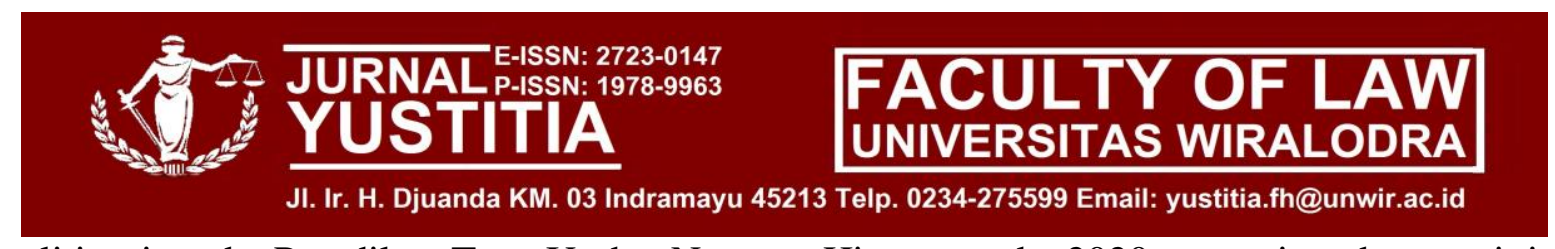

elitigasi pada Peradilan Tata Usaha Negara. Hingga pada 2020 sampai pada saat ini, terjadilah penerapan e-litigasi di seluruh wilayah pengadilan di Indonesia termasuk didalamnya yaitu Peradilan Tata Usaha Negara pastinya. Berikut ini merupakan rangkaian dari proses administrasi secara elektronik, yaitu meliputi beberapa proses diantaranya yaitu sebagai berikut proses penerimaan gugatan, proses penyampaian panggilan, jawaban, replik, duplik, kesimpulan, penyampaian dan penerimaan perkara tata usaha negara ${ }^{15}$.

Ketika pertama kali adanya pembentukan serta pemberlakuan Peraturan Mahkamah Agung No. 3 Tahun 2018, akhirnya ditetapkanlah 6 Pengadilan Tata Usaha Negara (PTUN) yang mana keenam Pengadilan Tata Usaha Negara tersebut dijadikan sebagai Satuan Kerja Percontohan dalam hal pelaksanaan Peradilan melalui sistem elektronik atau yang selanjutnya kita sebut e-court, diantaranya yaitu Pengadilan Tata Usaha Negara Tanjungpinang, Pengadilan Tata Usaha Negara Serang, Pengadilan Tata Usaha Negara Jakarta, Pengadilab Tata Usaha Negara Bandung, Pengadilan Tata Usaha Negara Denpasar serta terakhir yaitu Pengadilan Tata Usaha Negara Makassar. Hingga sampai pada bulan Desember tahun 2018, telah berdiri 18 Peradilan Tata Usaha Negara yang siap sehingga diharapkan mampu serta loyal dalam menyelenggarakan Peradilan Tata Usaha melalui sistem e-court ${ }^{16}$.

Dalam pelaksanaan Peradilan tata usaha negara melalui sistem e-court, terdapat sebuah regulasi terkait dengan Pembatasan layanan e-Court yang mana hanya pada sebatas perkara gugatan ini lebih kepada dikarenakan sebuah pertimbangan efektivitas e-Court, menimbang sebuah perkara Permohonan ialah sebuah sistem baru dalam Peradilan Tata Usaha Negara, yang mana jumlah perkaranya cenderung belum terlalu banyak jika dikomparasikan dengan perkara gugatan ${ }^{17}$. Kemudian setelah e-Court yang ditujukan untuk suatu perkara gugatan yang telah berjalan dengan lancar, maka Mahkamah Agung sesegera mungkin harus mulai menciptakan sebuah aplikasi e-Court yang diperuntukkan untuk suatu perkara Permohonan. Guna mendapatkan suatu gambaran utuh mengenai penyelenggaraan Peradilan Tata Usaha Negara secara elektronik atau melalui E-court, maka berikut ini merupakan beberapa tahapan selama proses Peradilan Tata Usaha Negara

\footnotetext{
${ }^{15}$ Indonesia, P. M. A. N. Administrasi Perkara Dan Persidangan Di Pengadilan Secara Elektronik. 2019.

${ }^{16}$ Sudarsono, Konsep Peradilan Secara Elektronik DI Lingkungan Peradilan TataUsaha Negara. Tanjungpura Law Journal, 2019, Vol. 3, Issue 1, hlm. 44.

17 Berdasar kepada Data Sistem Informasi Penelusuran Perkara (SIPP) PTUN seIndonesia,bahwasanya jumlah perkara Permohonan pada PTUN di seluruh Indonesia sampai tanggal 15 Desember 2018 adalah sebanyak 120 perkara.
} 


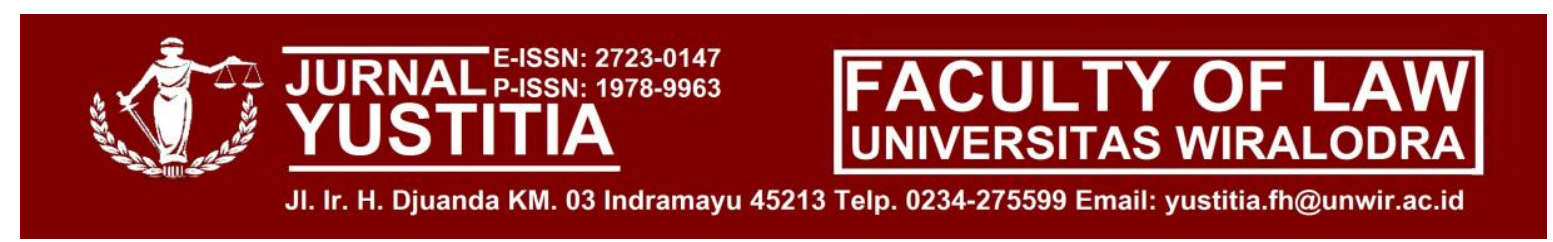

secara elektronik, diantaranya yaitu terdapat tahap pertama yaitu pendaftaran akun pengguna terdaftar, selanjutnya yang kedua yaitu tahap pendaftaran perkara, kemudian ketiga adalah tahap pemanggilan, keempat merupakan tahap persidangan, dan kelima sekaligus tahap perakhir yaitu tahap penerbitan putusan.

Pada dasarnya, dengan adanya sistem E-court dalam pengadaan persidangan Tata Usaha Negara di Indonesia dengan berbagai implikasinya, merupakan suatu hal yang memberikan sebuah kemajuan tersendiri bagi sistem peradilan di Indonesia pada umum nya dan pada penradilan Tata Usaha Negara pada khususnya, dikarenakan dengan adanya sistem e-court inilah, kemajuan akan teknologi informasi yang pesat, telah lebih digunakan dengan maksimal kedalam hal yang positif dan menguntungkan. Beberapa aspek efisiensi, kesederhanaan dan penghematan biaya dapat terpenuhi melalui pengadaan peradilan Tata Usaha Negara di Indonesia dengan sistem E-court, meski sesungguhnya tidak hanya dalam hal peradilan tata usaha negara, akan tetapi karena fokus pada penulisan ini pada peradilan tata usaha negara, maka hal tersebut telah memberikan konsep berfikir yang baik serta menjembatani masyarakat untuk lebih memanfaatkan pengadaan sistem e-court tersebut.

Meskipun suatu hal yang pasti, apabila terdapat suatu hal aturan ataupun sistem baru, maka tidak dapat untuk langsung serta merta diterapkan pada seluruh lapisan dan peradilan di Indonesia oleh karena adanya upaya penyesuaian. Sehingga dalam hal ini memang masih diperlukan adanya upaya penyesuaian terkait dengan adanya peraturan baru mengenai pengadaan sistem e-court di Indonesia sebagaimana yang telah kita ketahui yaitu pada Peraturan Mahkamah Agung No 1 Tahun 2019, yang mana notabenenya hal tersebut adalah suatu peraturan baru yang membutuhkan adanya upaya pembelajaran mengenai hal ini lebih lanjut terutama pada masyarakat umum yang biasanya cenderung kurang memahami terkait dengan sistem tersebut meskipun sebenarnya akan lebih memudahkan masyarakat dalam sengketa tata usaha negara yang dialaminya.

Maka, ketika suatu peraturan di undangkan, dalam hal ini yaitu peraturan mahkamah Agung mengenai sistem e-court dalam penerapan di wilayan peradilan, dan peradilan tata usaha negara, maka tidak cukup hanya kepada diselesaikan peraturan tersebut, akan tetapi lebih kepada bagaimana upaya agar peraturan tersebut dapat dimengerti serta dipahami oleh berbagai lapisan masyarakat, sehingga adanya perubahan dari Peraturan Mahkamah Agung No. 3 Tahun 2018, menjadi Peraturan Mahkamah Agung No. 1 Tahun 2019, yang tentu sudah pasti didalamnya memiliki tujuan baik untuk sistem 


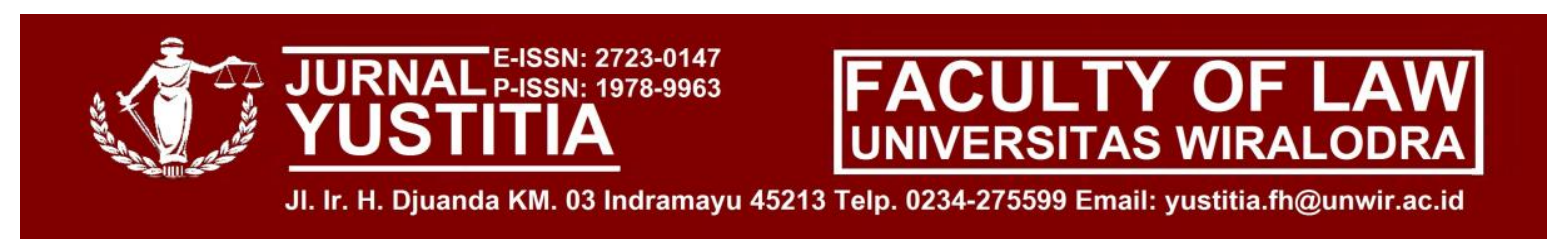

peradilan di Indonesia, tidak sia sia dan tercapai secara menyeluruh dan merata sekaligus agar dapat memberikan pemahaman hukum beserta sistem persidangannya, karena berdasarkan fakta di Indonesia hingga sampai saat ini, pengetahuan masyarakat Indonesia akan hukum beserta proses penegakan serta peradilannya, masih dapat dikatakan cenderung tidak terlalu baik, dikarenakan kurangnya upaya persebaran yang merata, serta kurangnya antusiasme masyarakat dalam hal mempelajarinya.

Proses Peradilan tata usaha negara melalui sistem E-court ini wajib dilaksanakan melalui cara yang sederhana, biaya yang tidak mahal atau murah dan terjangkau, serta cepat dalam pemrosesannya, sebagaimana yang telah diamanatkan dan tertuang dalam Pasal 2 Ayat (4) Undang-undang Nomor 48 Tahun 2009 tentang Kekuasaan Kehakiman. Penjelasan tersendiri daripada asas sederhana yaitu sebuah asas pemeriksaan beserta penyelesaian perkara yang mana didalamnya diselenggarakan dengan efektif serta efisien. Kemudian terkait dengan asas cepat tersebut tidak dijelaskan dengan terperinci entah itu pada Pasal 2 Ayat (4) Undang-Undang Kekuasaan Kehakiman ataupun di bagian penjelasannya, namun pada dasarnya prinsip cepat tersebut tentunya mengacu kepada waktu dalam proses penyelesaian perkara, yang mana dalam proses tersebut di dalam proses pemeriksaan harus dilaksanakan secara cepat, dimana itu berarti dalam proses pemeriksaan perkara dalam pengadilan tidak mesti dilakukan dalam waktu yang lama. Terakhir, terkait dengan maksud dari asas biaya ringan atau terjangkau yaitu suatu asas dimana biaya perkara tersebut terjangkau dan tentunya meringankan masyarakat, serta dapat memberikan sebuah kepastian hukum ${ }^{18}$.

Disamping hal hal tersebut diatas, terdapat banyak manfaat dengan diadakannya sistem peradilan Tata usaha negara melalui sistem e-court. Selain yang sudah dijelaskan diatas bahwasanya memiliki manfaat yaitu sederhana lebih cepat dan murah, sejatinya penggunaan sistem ini di peradilan Indonesia juga akan menekan kemungkinan kemungkinan adanya perilaku penyimpang dalam proses peradilan yang mana hal tersebut adalah kecurangan seperti menyuap, kemudian dalam hal lainnya yaitu untuk administrasi perkara lebih ringan serta lebih mudah, kemudian memenuhi asas manfaat ${ }^{19}$, sebagai contoh yaitu bagi warga yang bertempat tinggal di daerah perkotaan dengan segala macam

\footnotetext{
${ }^{18}$ Siti, Kusnadi. Penerapan Sistem E-Court di Pengadilan Tata Usaha Negara Makassar Pespektif Siyasah Syar'iyyah. Makassar, Siyasatuna, 2020, Volume 2 (3), hlm. 588-589.

${ }^{19}$ Hidayat, dkk, Kajian Kritis Terhadap Dualisme Pengadilan Elektronik (ECourt) Dan Konvensional. Batulis Civil Law Review, 2020, Volume 1 (1), hlm. 14-23.
} 


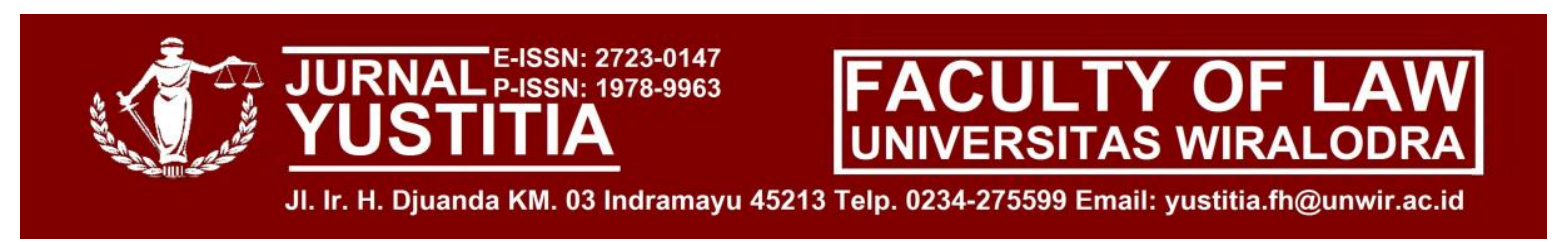

kepluralitasan hidupnya yang tentu sudah sangat modern dan sesuai dengan kemajuan jaman terutama dibidang teknologi, maka hal tersebut akan menjadikan pemanfaatan sistem ecourt dalam proses peradilan akan dianggap jauh lebih bermanfaat dikarenakan untuk setiap tuntutan maupun hak hak yang dilayangkan oleh pihak terkait yang berperkara serta pihak tersebut memiliki jasa kuasa hukum dalam proses peradilannya, sehingga sistem e-court tersebut mampu melakukan penghematan waktu daripada ketika mereka memakai sistem peradilan konvensional, sehingga dalam hal pemenuhan asas manfaat, sistem ini akan lebih efisien dalam mempersingkat proses penyelesaian perkara, serta bisa silaksanakan dalam waktu yang sama dikarenakan seluruh kegiatan peradilan tata usaha negara melalui sistem e-court tersebut berlangsung secara online.

Kemudian point manfaat penggunaan sistem e-court dalam proses peradilan tata usaha negara yang selanjutnya yaitu dokumen dokumen dapat terarsip dengan baik sekaligus dapat diakses melalui beberapa lokasi dan media. Manfaat selanjutnya yang tidak akan dapat kita lupakan terkait dengan fenomena alam saat ini, yaitu adanya penyebaran covid 19, tentu kita semua telah mengetahui betul terkait dengan bagaimana bahaya dari adanya penyebaran pandemi covid 19, sehingga dengan adanya sebuah kemudahan dalam hal menyelenggarakan proses peradilan tata usaha negara melalui sistem e-court, akan sangat membantu dan memberikan dampak besar bagi penekanan jumlah penyebaran virus berbahaya tersebut serta melindungi masyarakat agar tetap terjaga dari kemungkinan kemungkinan penularan wabah pandemi covid 19. Hal tersebut tentu sudah sewajarnya ada dan terfikirkan alternatif nya untuk keseimbangan serta kestabilan dan keefektifan proses peradilan tata usaha negara di Indonesia.

Dan point manfaat terakhir dari pengadaan sistem e-court dalam proses peradilan tata usaha negara yaitu meminimalisir adanya kesalahan kesalahan yang mungkin terjadi. Pada sistem pengadaan E-court dalam peradilan tata usaha negara, dapat menepiskan kemungkinan kemungkinan terjadinya sebuah kesalahan dalam setiap proses penyelesaian suatu perkara, dikarenakan data data para pihak terkait yang dikirim dapat dilakukan upaya perubahan untuk perbaikan serta dilakukan proses verifikasi agar dapat diandalkan dalam hal kevalidan serta kebenarannya. Dari beberapa manfaat e-court tersebut, maka sudah pasti dapat ditarik sebuah kesimpulan bahwasanya eksistensi pengadaan peradilan tata usaha negara pada khususnya maupun pengadaan proses peradilan pada umumnya melalui sistem e-court ini dapat memberikan dampak positif dan keberhasilan peradilan Indonesia 


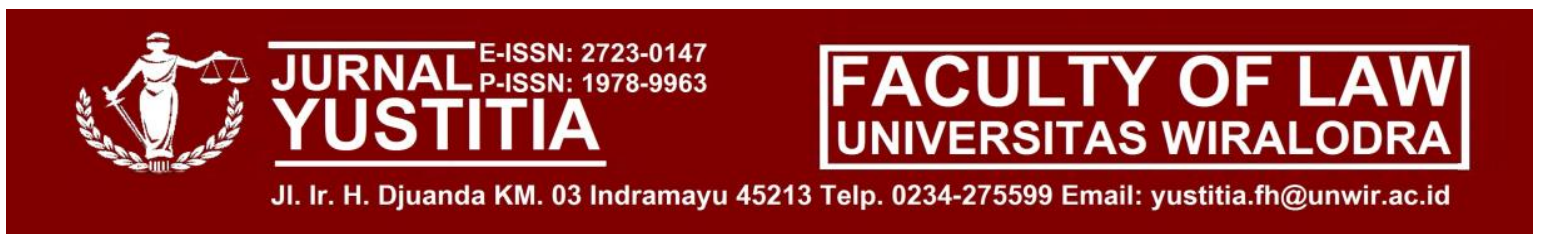

yang cukup signifikan entah itu di masa masa biasa ataupun ketika dalam hal genting seperti adanya covid 19. Dan sebagaimana yang telah kita bahas dan ketahui, bahwasanya sistem E-court ini telah ternaungi oleh payung hukum yang terkandung dalam Peraturan Mahkamah Agung Indonesia Nomor 1 Tahun 2019 tentang Administrasi Perkara Di Pengadilan Secara Elektronik.

\section{PENUTUP}

\section{A. Simpulan}

1. Pengadaan Peradilan Tata Usaha Negara melalui sistem E-court telah memiliki sebuah jaminan serta pengaturan dan atau payung hukum yang pasti, yaitu dalam Peraturan Mahkamah Agung Nomo 1 Tahun 2019 yang mana sebelumnya diatur dalam Peraturan Mahkamah Agung Nomor 3 Tahun 2018. Terdapat beberapa tahapan dalam proses persidangan tata usaha negara melalui sistem e-court diantaranya yaitu terdapat tahap pertama yaitu pendaftaran akun pengguna terdaftar, selanjutnya yang kedua yaitu tahap pendaftaran perkara, kemudian ketiga adalah tahap pemanggilan, keempat merupakan tahap persidangan, dan kelima sekaligus tahap perakhir yaitu tahap penerbitan putusan.

2. Pengadaan sistem e-court dalam proses peradilan ini telah membawa implikasi cukup bagus dan signifikan bagi perkembangan peradilan di Indonesia pada umumnya dan peradilan tata usaha negara pada khususnya, dikarenakan sistem ecourt merupakan bentuk dari adanya kesadaran perkembangan teknologi informasi yang kemudian dimanfaatkan dengan baik dan di selenggarakan dengan tanpa siasia. Beberapa manfaat dapat diperoleh dari pengadaan sistem e-court ini, salah satunya yaitu membantu menekan dan mengurangi laju penyebaran pandemi covid 19, meningkatkan efektifitas serta efisiensi waktu, menyederhanakan proses serta menghemat biaya agar dapat teraplikasikan bagi seluruh rakyat Indonesia. Hal yang perlu dibenahi adalah terkait dengan penyebaran sosialisasi terkait dengan pengetahuan akan adanya sistem e-court ini, agar dapat dinikmati oleh masyarakat Indonesia dari berbagai kalangan serta mewujudkan tujuan dari pengadaan sistem e-court ini dengan lebih signifikan lagi agar semua masyarakat dapat memahami dan mengerti. 


\section{B. Saran}

Proses pengadaan peradilan tata usaha negara melalui sistem e-court ini tentunya tidak dapat dinikmati oleh semua kalangan masyarakat untuk mengetahui dan menguasainya, bahkan barangkali para aparatur penegak hukum pun belum sepenuhnya mengerti. Maka, untuk menjamin keberhasilan sistem ini, lebih baik jika hal tersebut tidak hanya sampai pada di undangkannya peraturan mahkamah agung no 1 tahun 2019 tersebut, dengan cara memberikan pengertian dan sosialisasi terhadap seluruh lapisan masyarakat, karena ketika semakin banyak masyarakat yang melek dan mampu memahami proses hukum, akan lebih memudahkan kita semua di masa mendatang untuk menjalani. Disamping itu, pengetahuan terhadap penegak hukum pun tetap harus dilakukan agar dikemudian hari tidak terjadi sebuah penyimpangan yang merugikan negara, ataupun masyarakat atau bahkan nama baik hukum dan keadilan, sehingga proses penegakan hukum melalui sistem e-court ini diharapkan mampu memberikan sebuah inovasi serta perbaikan dalam hal penegakan hukum khususnya pada peradilan tata usaha negara yang lebih baik.

\section{DAFTAR PUSTAKA}

\section{A. Buku :}

Arief, Barda Nawawi. 2010. Bunga Rampai Kebijakan Hukum Pidana, Perkembangan Penyusunan Konsep KUHP Baru, Jakarta: Kencana Prenada Media Group

Arief, Barda Nawawi. 2010. Masalah Penegakan Hukum dan Kebijakan Hukum Pidana dalam Penanggulangan Kejahatan, Jakarta: Kencana Prenada Media Group. $7-261$

M. Cheris Bassiouni, Substantive Criminal Law, 1978,

Reza Indragiri Amriel. 2008. Psikologi Kaum Muda Pengguna Narkoba. Salemba Humanika. Jakarta.

Sajipto Rahardjo, Ilmu Hukum, Bandung: PT Citra Aditya Bakti, 2014

Soerjono Soekanto \& Sri Mamudji, Penelitian Hukum Normatif (Suatu Tinjauan Singkat). Jakarta: PT Raja Grafindo Persada, 2006) 


\section{B. Jurnal}

Angrayni, Lysa. 2018. Efektivitas Rehabilitasi Pecandu Narkotika (Studi di Loka Rehabilitasi Badan Narkotika Nasional Batam), Jurnal Hukum Respublica. Vol.18.No.1, hlm.78-96.

Dewan, Parasian Simanungkalit. 2012. Model Pemidanaan Yang Ideal Bagi Korban Pengguna Narkoba Di Indonesia. Jurnal Yustitia. Vol. 1.No. 3, hlm. 80-93.

Fitri, Silvia. 2020. Implementasi Kebijakan Rehabilitasi Pengguna Narkoba pada Badan Narkorika Nasional Provinsi Sumatera Barat. Jurnal of Civic Education. Vol. 3. No. 3, hlm. 231- 242.

Hartanto, Wenda. 2017. Penegakan Hukum Terhadap Kejahatan Narkotika dan Obat-

Obat Terlarang Dalam Era Perdagangan Bebas Internasional Yang Berdampak Pada Keamanan dan Kedaulatan Negara. Jurnal Legislasi Indonesia. Vol.14.No.1, hlm.1-16.

Purnamasari, Andi Intan.2019. Dekriminalisasi Tindak Pidana: Membedah Keadilan Bagi Terpidana Dan Mantan Terpidana.Vol.2 No.1, hlm. 13-23.

Subantara, I Made, A.A. Sagung Laksmi Dewi, \& Luh Putu Suryani. 2020. Rehabilitasi Terhadap Korban Penyalahgunaan Narkotika Di Badan Narkotika Nasional Provinsi Bali. Jurnal Preferensi Hukum. Vol.1 No.1, hlm. 243-248.

\section{Sumber Lain}

Asprilla Dwi Adha. 2021. Over Kapasitas Lapas, Pemerintah Dituding Melanggar HAM. $\quad$ https://www.cnnindonesia.com/nasional/20210912173723-12693210/over-kapasitas-lapas-pemerintah-dituding-melanggar-ham. Diakses 25 September 2021

Deden Gunawan. 2021. Tiga Alasan Pengguna Narkoba Banyak Dijebloskan Ke Penjara. $\quad$ https://news.detik.com/berita/d-5726803/tiga-alasan-penggunanarkoba-banyak-dijebloskan-ke-penjara. Diakses 26 September 2021

Humas Balitbangkumham. 2019. Hanya Sedikit Napi Narkotika Yang Terima Rehabilitasi. https://www.balitbangham.go.id/detailpost/hanya-sedikit-napinarkotika-yang-terima-rehabilitasi. Diakses 25 September 2021

Humas BNN.2015. Dekriminalisasi Pengguna Narkoba Tidak Sama Dengan Legalisasi. https://bnn.go.id/dekriminalisasi-pengguna-narkoba-tidak-samadengan-legalisasi/. Diakses 26 September 2021 


\section{JURNALE-ISSN: 2723-0147}

JURNALP-ISSN: 1978-9963

YUSTITIA

JI. Ir. H. Djuanda KM. 03 Indramayu 45213 Telp. 0234-275599 Email: yustitia.fh@unwir.ac.id

Humas BNN.2019. Narapidana Narkotika Membeludak Dimana Letak

Permasalahannya. https://bnn.go.id/narapidana-narkotika-membeludakdimana-letak-permasalahannya/ . Diakses 25 September 2021.

Kanwil Sulawesi Selatan. 2019. Restoratijuztice, Solusi Over Kapasitas Lapas Rutan. https://sulsel.kemenkumham.go.id/pusat-informasi/artikel/4443restorativejustice-solusi-over-kapasitas-lapas-rutan. Diakses 25 September 2021.

Kominfo 2015. BNN Ingatkan 50 Orang Meninggal Setiap Hari Karena Narkoba. https://kominfo.go.id/content/detail/4883/bnn-ingatkan-50-orang-meninggal -setiap-hari-karenanarkoba/0/sorotan_media. Diakses 26 September 2021 